\title{
Post World War II politics and Keynes's aborted revolutionary economic theory
}

\author{
Paul Davidson ${ }^{1}$
}

\begin{abstract}
"...in the General Theory ...injustice becomes a matter of uncertainty, justice a matter of contractual predictability" (Skidelsky, 1992, p. 223).

"The terms in which contracts are made matter. In particular, if money is the goods in terms of which contracts are made, then the prices of goods in terms of money are of special significance. This is not the case if we consider an economy without a past or future... if a serious monetary theory comes to be written, the fact that contracts are made in terms of money will be of considerable importance" (Arrow; Hahn, 1971, p. 356-357, italics added).

"In the first place, the fact that contracts are fixed... in terms of money unquestionable plays a large part" (Keynes, 1936, p. 236).

"It seems to me that economics is a branch of logic: a way of thinking... One can make some quite worthwhile progress merely by using axioms and maxims. But one cannot get very far except by devising new and improved models. This requires... vigilant observation of the actual working of our system. Progress in economics consists almost entirely in a progressive movement in the choice of models" (Keynes, 1938).
\end{abstract}

In an often quoted 1935 letter to George Bernard Shaw Keynes indicated that he was writing a book that would revolutionize economic theory where liquidity and money contracts play a dominant role in the organization of production and exchange processes. For more than two decades after World War II most mainstream economists believed they were teaching their students Keynes's revolutionary theory and its policy implications. In 1971 even an American President, Richard M. Nixon, announced "now I am a Keynesian". Today however, the teaching of "Keynesianism" is virtually dead, at least in mainstream economic textbooks, the analysis of recent economic Nobel Laureates, and speeches of governmental policy makers whether they be "liberal" or "conservative". Indeed the current sub prime mortgage credit crisis in the U.S. and its global financial implications has not been properly analyzed by politicians and Central Bankers because their mainstream economic advisors do not understand Keynes's analytical framework.

This paper attempts to explain the death blow given to this revolutionary analysis developed by the greatest thinker in economics in the 20th century.

(1) Editor of the Journal of Post Keynesian Economics (JPKE). E-mail: pdavidso@utk.edu. 
Paul Davidson

Keynes's biographer, Lord Skidelsky (1992, p. 512) has noted that "mainstream economists after the Second World War treated Keynes's theory as a 'special case' of the classical theory, applicable to conditions where money wages... were 'sticky'. Thus his theory was robbed of its theoretical bite, while allowed to retain its relevance for policy". If Keynes theory is that unemployment is the result of price and wage rigidities, then Keynes was nothing new or revolutionary. For even in the 19th century classical economists had argued that the lack of flexible wages and prices (supply side imperfections) is the cause of unemployment.

Keynes specifically denied that the fundamental cause of unemployment is wage and/or price rigidities. In The General Theory Keynes wrote (1936, p. 257): "the Classical Theory has been accustomed to rest the supposedly selfadjusting character of the economic system on an assumed fluidity of money wages; and when there is a rigidity, to lay on this rigidity the blame of maladjustment... My difference from this theory is primarily a difference of analysis." Given this Keynes statement, how could mainstream economists after the second world war ever conceived that Keynes's theory required sticky wages, prices, or even an absolute liquidity trap (i.e., a fixed minimum interest rate $^{2}$ ) to demonstrate the existence of involuntary unemployment?

A sage once said that the definition of a "classic" is a book that everyone cites but no reads. Mainstream economists who call themselves "Keynesians", and yet attribute unemployment to wage, price or interest rate rigidities, must think of Keynes's General Theory as a literary classic that they can cite without bothering to read or understand Keynes's serious monetary theory.

What is revolutionary in Keynes's analytical framework? Some believe it is the concept of the multiplier. But if that was true than we ought to call it the Kahnian revolution since it was Keynes's student, Richard Kahn, that invented the multiplier. On page 16 of The General Theory Keynes, however, indicated what revolutionary path he was following, when he wrote: "The classical theorists resemble Euclidean geometers in a non-Euclidean world who, discovering that in experience straight lines apparently parallel often meet, rebuke the lines for not keeping straight - as the only remedy for the unfortunate collisions which are occurring. Yet, in truth there is no remedy except to throw over the axioms of

(2) This sticky interest rate argument is called the "liquidity trap" where at some low, but positive, rate of interest the demand to hold money for speculative reasons is assumed to be perfectly elastic (i.e., horizontal). After the Second World War, econometric investigations could find no evidence of a liquidity trap. Had mainstream economists read The General Theory, however, they would have known that on page 202 Keynes specifies the speculative demand for money as a rectangular hyperbola - a mathematical function that never has a perfectly elastic segment. Moreover, eyeball empiricism led Keynes (1936a, p. 207) to indicate that he knew of no historical example where the liquidity preference function became "virtually absolute", i.e., perfectly elastic. In sum, both from a theoretical and an empirical view, Keynes denied the existence of a liquidity trap. 
parallels and to work out a non-Euclidean geometry. Something similar is required today in economics". So Keynes overthrew three classical axioms, (1) neutrality of money, (2) the gross substitution axiom; and (3) the ergodic axiom. ${ }^{3}$ In the absence of these three axioms, Keynes's analysis of uncertainty and the role of money and money contracts in organizing production and distribution is the foundation of a non-Euclidean revolution in economics.

\section{What aborted this revolutionary analysis?}

Keynes's revolution was never understood by the founders of Keynesianism after World War II. Moreover the political atmosphere of the time discouraged those who might have attempted to explain Keynes's revolutionary theory. To illustrate the problem we will use the example of Paul Samuelson's attempt to propagate Keynesianism and compare it with Keynes's revolutionary monetary theory.

At the end of the talk we will explain why, beginning in the 1970s, J. R. Hicks, progenitor of the ISLM version of neoclassical Keynesianism and winner of the Nobel Prize in 1972 for his "pioneering contributions to general equilibrium theory", recognized that his classical general equilibrium analysis of Keynes - the ISLM version of Keynesianism - was not representative of Keynes's general theory framework. In the 1980s, Hicks announced he was after all a Post Keynesian and was now "labeling my own point of view as nonergodic".

\section{Samuelson's neoclassical synthesis Keynesianism}

For most students who studied economics during the last half of the 20th century, Samuelson was thought to be a direct disciple of Keynes. Samuelson is usually considered the founder of the American Keynesian school which he labeled Neoclassical Synthesis Keynesianism because of the classical microeconomic theory that Samuelson had developed in his Foundations of Economic Analysis (1947) that Samuelson claimed was the micro foundation of Keynes's macro analysis. Unfortunately Samuelson's neoclassical synthesis brand of "Keynesianism" is not analytically compatible with Keynes's theoretical framework

Given Samuelson's dominance of the American macroeconomic scene after the second world war, the different axiomatic foundation of Samuelson's popularization of Keynesianism vis-a-vis Keynes's General Theory aborted Keynes's truly revolutionary analysis from being adopted. Consequently in the 1970s, the Monetarists easily defeated Samuelson's 'Keynesianism' on the

(3) For a complete discussion of these axioms and why they made Keynes's theory revolutionary see Davidson, (2007, chapt. 4, 7).

Economia e Sociedade, Campinas, v. 17, Número especial, p. 549-568,dez. 2008. 
Paul Davidson

grounds of logical inconsistency between its microfoundations and its "Keynesian" macroeconomic policy prescriptions. The effect of this defeat was to change the domestic and international choice of policies (1) to prevent unemployment, (2) to promote economic development, and (3) today to understand how the American subprime mortgage credit crisis is infecting financial markets around the world away from prescriptions founded on Keynes's revolutionary analysis and towards the age-old laissez-faire policies promoted by classical theory.

As a result of the Monetarist victory over Samuelson's Keynesianism in the 1970s, New Keynesian theory as espoused by Mankiw and others tended to replace Samuelson's Keynesianism. Just as Friedman's Monetarism had conquered Samuelson's brand of Keynesianism, however, New Classical theory and its concept of rational expectations easily made a mockery of the New Keynesians approach which relied on the rigidity of wages and prices to achieve Keynesian-like results. Rational expectations required the ergodic axiom as a basis and therefore presumed that with free markets there already existed a full employment economic future that human actions and government policies could not alter. Accordingly, the New Classicists could argue that our economic problems were associated with supply side problems primarily due to government interference that prevented free competition in the labor and product market place. The result was to lead policy makers to dance to the Panglossian siren song that "all is for the best in the best of all possible worlds provided we let well enough alone" (Keynes, 1936, p. 33) by encouraging adoption of policies of "liberalizing" all domestic and international markets for trade and finance.

\section{The coming of Keynesianism to America}

In their wonderful book The Coming of Keynesianism to America, Colander and Landreth (1996, p. 23) (hereafter C-L) credit Paul Samuelson with saving the textbook pedagogical basis of the Keynesian Revolution from destruction by the anti-communist spirit (McCarthyism) that ravaged America academia in the years immediately following the second world war.

Lori Tarshis, a Canadian who had been a student attending Keynes's lectures at Cambridge during the early 1930s had, in 1947, wrote an introductory textbook that incorporated Tarshis' lecture notes interpretation of Keynes's General Theory. Despite the initial popularity of the Tarshis textbook, its sales declined rapidly as trustees of and donors to American colleges and universities, attacked Tarshis's book as preaching an economic "socialist" heresy. The frenzy about Tarshis's textbook reached a pinnacle when William F. Buckley, in his book God and Man at Yale (1951), attacked the Tarshis analysis as communist inspired. 
In 1986 C-L interviewed Samuelson, (C-L, 1996, p. 145-178) about his becoming an economist and a "Keynesian". Samuelson indicated that he recognized the "virulence of the attack on Tarshis" and so he wrote his textbook "carefully and lawyer like" (C-L, 1996, p. 172). The term "neoclassical synthesis Keynesianism" did not appear in the first edition of Samuelson's textbook, (1948), which was published after the early attacks on Tarshis's text. This neoclassical synthesis terminology, however, does appears prominently in the later editions of Samuelson's textbook. Samuelson's assertion that his brand of Keynesian macroeconomics is synthesized with (and based on) traditional neoclassical microeconomic assumptions made the Samuelson version of Keynesianism less open to attacks of bringing economic heresy into University courses on economics compared to Tarshis's Keynesian analysis.

Unlike Tarshis's analysis which was based on separate aggregate supply and demand functions, the analytical foundation of Samuelson's Keynesianism was imbedded in Samuelson's 45 degree Keynesian cross. This mathematical derivation in conjunction with the claimed synthesis of neoclassical theory made it more difficult to attack the Samuelson version of textbook Keynesianism as communist motivated. Thus for several generations of economists educated after World War II, Samuelson's name was synonymous with Keynesian theory as various editions of Samuelson's neoclassical Keynesian textbook - the best selling economics textbook of all times with over a million copies sold - dominated the teaching of economics. Even those younger economists who developed their own branch of New Keynesianism based their analytical approach on the Samuelson's Foundation of Economic Analysis (1947) and its classical microeconomic axiomatic foundations.

From an historical perspective it appears that Samuelson saved the textbook pedagogical basis of the Keynesian Revolution from McCarthyism destruction simply by ignoring the less restrictive axiomatic foundation of Keynes's analytic revolution and thereby destroying Keynes's revolutionary theory.

\section{How did Samuelson learn Keynes's theory?}

In his 1986 interview Samuelson indicated that in the period before World War II, "my friends who were not economists regarded me as very conservative" (C-L, 1996, p. 154). Samuelson graduated the University of Chicago in June 1935 and were it not for the Social Science Research Council fellowship that he received upon graduation, he would have done his graduate studies at the University of Chicago (C-L, 1996. p. 154-155). It was the visible hand of a fellowship offer that placed Samuelson at Harvard when Keynes's General Theory 
was published in 1936. What information about Keynes's General Theory was Samuelson exposed to at Harvard?

Robert Bryce, a Canadian, had attended the same Keynes's Cambridge lectures as Tarshis between 1932 and 1935. In a 1987 interview with Colander and Landreth (1996, p. 39-48) Bryce indicated that in Spring of 1935 he (Bryce) spent half of each week at the London School of Economics and half at Cambridge. At LSE Bryce used his Cambridge lecture notes to write an essay on Keynes's revolutionary ideas - without having read The General Theory - for the people at the LSE. Bryce's essay so impressed Hayek that Hayek let Bryce have four consecutive weeks of Hayek's seminar to explain Keynes's ideas as he had written them out in this essay. Bryce's lectures were a huge success at the LSE (C-L, 1996, p. 43).

In the fall of 1935 Bryce went to Harvard and stayed for two years. During that time, informal groups met during the evenings to discuss Keynes's book. Bryce, using the same pre-General Theory essay that he had used as the basis for his talks at the LSE, presented to these groups what he believed was Keynes's General Theory analysis -- although he still had not read the General Theory. As Bryce put it, "In most of the first academic year (1935-36) I was the only one who was familiar enough with it (Keynes' theory) to be willing to argue in defense of it" (C-L, 1996, p. 45-46). So in 1936 Bryce's essay became the basis of what most economists at Harvard, probably including Samuelson, thought was Keynes's analysis - even though Bryce had not read the book when he made his presentations. Even in 1987, Bryce stated that, " anyone who studies that book is going to get very confused. It was... a difficult, provocative book" (C-L, 1996, p. 44-46).

Did Bryce ever really comprehend the basis of Keynes's analytical framework? And if he did not, how did that affect how the young Samuelson and others at Harvard in 1936 learn about Keynes's analytical framework? Bryce's presentations at the LSE and Harvard were supposed to make Keynes's ideas readily understandable - something that Bryce believed Keynes could not do in his General Theory book. Bryce indicated that in his first year at Harvard "I felt like the only expert on Keynes's work around" (C-L, 1996, p. 45).

Samuelson states that his first knowledge of Keynes's General Theory was gained from Bryce (C-L, 1996, p. 158). Moreover, even after reading the General Theory in 1936, Samuelson, perhaps reflecting Bryce's view of the difficulty of understanding Keynes's book, found the General Theory analysis "unpalatable" and not comprehensible (C-L, 1996, p. 159). Samuelson indicated that "The way I finally convinced myself was to just stop worrying about it (about understanding Keynes's analysis). I asked myself: why do I refuse a paradigm that enables me to understand the Roosevelt upturn from 1933 till 1937? ... I was 
content to assume that there was enough rigidity in relative prices and wages to make the Keynesian alternative to Walras operative" (C-L, 1996, p. 159-160).

In 1986 Samuelson was still claiming that "we (Keynesians) always assumed that the Keynesian underemployment equilibrium floated on a substructure of administered prices and imperfect competition" (C-L, 1996, p. 160). When pushed by Colander and Landreth as to whether this requirement of rigidity was ever formalized in his work, Samuelson's response was "There was no need to" (C-L, 1996, p. 161).

Yet, as we already noted in chapter 19 of The General Theory Keynes rejected the rigidity of wage argument of unemployment. Even more directly in his published response to Dunlop and Tarshis, Keynes (1939b) had already responded in the negative to this question of whether his analysis of underemployment equilibrium required imperfect competition, administered prices, and/or rigid wages. Dunlop and Tarshis had argued that the purely competitive model was not empirically justified, therefore it was monopolistic and administered pricing and wage fixities that was the basis of Keynes's unemployment equilibrium. Keynes reply was simply: "I complain a little that I in particular should be criticised for conceding a little to the other view" (Keynes, 1939b, p. 411). In chapters 17-19 of his General Theory, Keynes explicitly demonstrated that even if a competitive economy with perfectly flexible money wages and prices existed ("conceding a little to the other view"), there was no automatic market mechanism that could restore the full employment level of effective demand. In other words, Keynes's general theory could show that, as a matter of logic, less than full employment equilibrium could exist even in a purely competitive economy with freely flexible wages and prices.

Obviously Samuelson, who became the premier American Keynesian of his time, had either not read, or not comprehended, (1) Keynes's response to Dunlop and Tarshis or even (2) chapter 19 The General Theory which was entitled "Changes in Money Wages".

Keynes (1936, p. 259) indicated that to assume that rigidity was the sole cause of the existence of an unemployment equilibrium lay in accepting the argument that the micro-demand functions "can only be constructed on some fixed assumption as to the nature of the demand and supply schedules of other industries and as to the amount of aggregate effective demand. It is invalid, therefore to transfer the argument to industry as a whole unless we also transfer the argument that the aggregate effective demand is fixed. Yet, this assumption reduces the argument to an ignoratio elenchi."

An ignoratio elenchi is a fallacy in logic of offering a proof irrelevant to the proposition in question. Unfortunately Samuelson invoked the same classical 
Paul Davidson

ignoratio elenchi when he argued that Keynes's general theory was simply a Walrasian general equilibrium system where, if there is an exogenous downward shock to aggregate demand, rigid wages and prices created a temporary disequilibrium that prevented full employment from being restored in the shortrun. ${ }^{4}$

As Keynes went on to explain, "whilst no one would wish to deny the proposition that a reduction in money wages accompanied by the same aggregate effective demand as before will be associated with an increase in employment, the precise question at issue is whether the reduction in money wages will or will not be accompanied by the same aggregate effective demand as before measured in term of money, or, at any rate, by an aggregate effective demand which is not reduced in full proportion to the reduction in money-wages" (Keynes, 1936, p. 259-60, see Davidson 1998 for an explicit diagrammatic analysis of this point). Keynes then spent the rest of chapter 19 explaining why and how a general theory analysis must look at the relationship between changes in money wages and/or prices and changes in aggregate effective demand - an analysis that, by assumption, is not relevant to either a Walrasian system or Samuelson's neoclassical synthesis Keynesianism.

At the same time that Samuelson became a Keynesian by convincing himself not to worry about Keynes's actual analytical framework, Tarshis had obtained a position at Tufts University, a mere half-hour of travel from Harvard. Tarshis would often met with a group at Harvard, including Bryce, who were discussing Keynes. Tarshis notes that "Paul Samuelson was not in the Keynesian group. He was busy working on his own thing. That he became a Keynesian was laughable" (C-L, 1996, p. 64).

Yet, Paul Samuelson has called himself a "Keynesian" and even a "Post Keynesian" in several editions of his famous textbook. Nevertheless, as we will explain infra, Samuelson's theoretical "neoclassical synthesis" axiomatic foundation is logically different from Keynes general theory of a monetary economy.

(4) The particular proof that Keynes claimed was irrelevant was the classical assertion that a fixed and unchanging downward sloping marginal product curve of labor was the demand curve for labor and so that falling wages must induce an increase in employment. In chapter 20 of The General Theory, Keynes specifically develops an "employment function" that is not the marginal product of labor curve and does not assure that aggregate effective demand is fixed. What the marginal productivity of labor curve indicates is that if in response to an expansion of aggregate effective demand, private sector entrepreneurs hire more workers to produce an additional flow of output per period, then in the face of diminishing returns (with no change in the degree of competition), the rise in employment will be associated with a fall in the real wage rate. In other words, the marginal product of labor curve is, for any given the level of effective demand and employment, the real wage determining curve. For a complete analysis of this point see Davidson (1998) or Davidson (2002). 
5 The axiomatic differences between Samuelson's neoclassical Keynesianism and Keynes's theory of a monetary economy

At the same time that Samuelson was developing his neoclassical synthesis Keynesianism, he was working on his masterful Foundations of Economic Analysis (1947). In his Foundations Samuelson asserts two specific classical axioms are the foundation of economic analysis and therefore, by extension, his neoclassical synthesis Keynesian macroeconomic analysis - the neutral money and the gross substitution axioms. For example Samuelson noted that utility functions are homogeneous of degree zero (Samuelson, 1947, p. 119121) and in a purely competitive world it would be foolish to hold money as a store of value as long as other assets had a positive yield (Samuelson, 1947, p. 122-124). These statements means that (1) money is neutral and (2) any real producible capital goods that produce a positive yield are assumed to be gross substitutes. Thus at the same time Samuelson was promoting his pedagogical brand of Keynesianism he was arguing that the gross substitution and the neutral money axioms are the foundation upon which all economic analysis must be built. But Keynes specifically rejected these two classical axioms.

Furthermore in an article published in 1969 Samuelson argued that the "ergodic hypothesis (axiom)" is a necessary foundation if economics is a hard science. (Samuelson, 1969, p. 184). Keynes also rejected this ergodic axiom.

What is this ergodic axiom? If one conceives of the economy as a stochastic process, then the future outcome of any current decision is determined via a probability distribution. Logically speaking to make statistically reliable forecasts about future economic events, the decision maker should obtain and analyze sample data from the future. Since that is impossible, the assumption of an ergodic stochastic process permits the analyst to assert that samples drawn from past and current data are equivalent to drawing a sample from the future. In other words, the ergodic axiom implies that the outcome at any future date is the statistical shadow of past and current market data.

The ergodic axiom therefore assures that the outcome associated with any future date can be reliably predicted by a statistical analysis of already existing data. The future is therefore never uncertain. The future can always be reliably predicted (actuarially known) by a sufficient statistical analysis of already existing data. Future outcomes, in an ergodic system, are probabilistically risky but are statistically reliably predictable from existing data. (In a nonstochastic 
deterministic orthodox economic model, the classical ordering axiom plays the same role as the ergodic axiom of classical stochastic models. ${ }^{5}$ )

Accordingly, in an ergodic stochastic world, in the long run, the equilibrium future is predetermined and can not be changed by anything human beings or governments do. It follows that any government market regulation or interference into normal competitive market (assumed ergodic) processes, may, in the short run, prevent the system from achieving the full employment level assured by the axioms of a classical Walrasian system. In an ergodic system where the future can be reliably predicted so that future positive yields of real capital producible assets can be known with actuarial certainty, and where the gross substitution axiom underlies all demand curves, then as long as prices are flexible, money must be neutral and the system automatically adjusts to a full employment general equilibrium.

If, on the other hand, in such an ergodic world prices are sticky in the short run, then it will take a longer time for the gross substitution theorem to work its way through the system but, at least in the long run, a full employment general equilibrium is still assured. Samuelson (C-L, 1996, p. 163) has stated that in his view Keynes's analysis is a "very slow adjusting disequilibrium" system where the "full Walrasian equilibrium was not realized" in the short-run because prices and wages do not adjust rapidly enough to an exogenous shock. Nevertheless the economic system would, if left alone, achieve full employment in the long run. In Keynes's general theory analysis, on the other hand a full employment equilibrium is not assured in either the short- or the long-run.

As we have noted Keynes's revolutionary analysis, however, requires economists to "throw over" of three restrictive classical axioms: (1) the neutrality of money axiom, (2) the gross substitution axiom, and (3) the axiom of an ergodic economic world. overthrew three classical axioms. To throw over an axiom is to reject what the faithful believe are "universal truths". Blanchard (1990, p. 828), for example, insists that all New Keynesian macroeconomic models must be based on "hard headed" microfoundations that "impose long-run neutrality of money as a maintained presumption (axiom). This is a matter of faith, based on theoretical considerations rather than on empirical evidence".

In 1935 Keynes explicitly noted that in his analytic framework money matters in both the long and short run, i.e., money is never neutral. Money affects real decision making. In 1935 Keynes wrote:

(5) True uncertainty occurs whenever an individual cannot specify and/or order a complete set of prospects regarding the future, either because: 1) the decision maker cannot conceive of a complete list of consequences that will occur in the future; or, ii) the decision maker cannot assign probabilities to all consequences because "the evidence is insufficient to establish a probability" so that possible consequences "are not even orderable" (Hicks, 1979, p.113, 115). In such cases the ordering axiom is not applicable. 
the theory which I desiderate would deal... with an economy in which money plays a part of its own and affects motives and decisions, and is, in short, one of the operative factors in the situation, so that the course of events cannot be predicted either the long period or in the short, without a knowledge of the behavior of money between the first state and the last. And it is this which we mean when we speak of a monetary economy... Booms and depressions are peculiar to an economy in which... money is not neutral... I believe that the next task is to work out in some detail a monetary theory of production... that is the task on which I am now occupying myself in some confidence that I am not wasting my time (Keynes, 1935, p. 408-409).

As Keynes's developed his theory of liquidity preference he recognized that his theory of involuntary unemployment required specifying "The Essential Properties of Interest and Money" (1936, ch. 17) that differentiated his results from classical theory. These "essential properties" assured that money and all other liquid assets ${ }^{6}$ are never neutral. These essential properties (Keynes, 1936, p. 230-231) are:

(1) the elasticity of production of all liquid assets including money is zero or negligible, and

(2) the elasticity of substitution between liquid assets (including money) and reproducible goods is zero or negligible.

A zero elasticity of production means that money does not grow on trees and consequently workers can not be hired to harvest money trees when the demand for money (liquidity) increases. Or as Keynes wrote: "money... cannot be readily reproduced; - labour cannot be turned on at will by entrepreneurs to produce money in increasing quantities as its price rises" (Keynes. 1936, p. 230).

In classical theory, on the other hand, money is a reproducible commodity. In many neoclassical textbook models as well as in the Walrasian general equilibrium system, peanuts or some other reproducible product of industry is the money commodity or numeraire. Peanuts may not grow on trees, but they do grow on the roots of bushes. In this case the propensity to save creates jobs just as much as the propensity to consume.

Keynes's "essential property" zero elasticity of substitution between liquid assets and the products of industry assures that the portion of income that is not spent on the products of industry for consumption purposes, i.e., what Keynes defined as savings, will find, in Hahn's (1977, p. 31) terminology, "resting places" in the demand for nonproducibles. Some forty years after Keynes, Hahn rediscovered Keynes's point that a stable involuntary unemployment equilibrium

(6) Liquid assets are defined as nonproducible financial assets that are traded in well organized and orderly markets (See Davidson, 1994, p. 49). 
could exist even in a Walrasian system with flexible wages and prices whenever there are "resting places for savings in other than reproducible assets" (Hahn, 1977, p. 31).

In Keynes's system, because of uncertainty, savings were held in the form of money and liquid assets that possess a zero elasticity of production. If the demand for nonproducibles increases (an increased demand for liquidity), the market price would rise proportionately. If, however, the elasticity of substitution between these nonproducibles and the products of industry is zero, then this rising price of liquid nonproducibles will not spill over into a demand for the products of industry.

Keynes (1936, p. 161) argued that the only "radical cure" for unemployment is "to allow the individual no choice between consuming his income and ordering the production of the specific capital asset which... impresses him as the most promising investment open to him. It might be that, at times when he was more than usually assailed by doubts concerning the future, he would turn in his perplexity towards more consumption and less investment... But that would avoid the disastrous, cumulative and far reaching repercussions of its being open to him, when thus assailed by doubts, to spend his income neither on the one or the other".

Hahn rigorously demonstrated what was logically intuitive to Keynes. Hahn (1977, p. 37) showed that the view that with "flexible money wages there would be no unemployment has no convincing argument to recommend it ... Even in a pure tatonnement in traditional models convergence to (a general) equilibrium cannot be generally proved" as long savings were held in the form of nonproducibles (e.g., money and other liquid assets). Hahn (1977, p. 39) demonstrated that "any non-reproducible asset allows for a choice between employment inducing and non-employment inducing demand". Accordingly, the existence of a demand for money and other liquid nonreproducible assets (that are not gross substitutes for the products of industries) as a store of "savings" means that all income earned by households engaging in the production of goods is not, in the short or long run, necessarily spent on the products of industry. Households who want to store that portion of their income that they do not consume (i.e., that they do not spend on the products of industry) in liquid assets are choosing, in Hahn's words "a non-employment inducing demand" for their savings.

If the gross substitution axiom was universally applicable, however, any new savings that would increase the demand for nonproducibles therefore would increase the price of nonproducibles (whose production supply curve is, by definition, perfectly inelastic). The resulting relative price rise in nonproducibles 
vis-à-vis producibles would, under the gross substitution axiom, induce savers to increase their demand for reproducible durables as a substitute for nonproducibles in their wealth holdings. Consequently, as in classical theory, nonproducibles could not be ultimate resting places for savings as they spilled over into a demand for producible goods (Cf. Davidson, 1972).

Samuelson's assumption that all demand curves are based on an ubiquitous gross substitution axiom implies that everything is a substitute for everything else. In Samuelson's foundation for economic analysis, therefore, producibles must be gross substitutes for any existing nonproducible liquid assets (including money) when the latter are used as stores of savings. Accordingly, Samuelson's Foundation of Economic Analysis denies the logical possibility of involuntary unemployment as long as all prices are perfectly flexible.

Samuelson's brand of Keynesianism is merely a form of the classical special case analysis that is "misleading and disastrous" (Keynes, 1936, p. 3) if applied to the operation of a monetary economy. In the absence of a restrictive universally applicable axiom of gross substitution, however, income effects (e.g., the Keynesian multiplier) can predominate and can swamp any hypothetical classical substitution effects. Just as in non-Euclidean geometry lines that are apparently parallel often crash into each other, in the Keynes-Post Keynesian nonEuclidean economic world, an increase demand for "savings" even if it raises the relative price of nonproducibles, will not spill over into a demand for producible good and hence when households save a portion of their income they have made a choice for "non-employment inducing demand".

Finally, Keynes argued that only in a money-using entrepreneur economy where the future is uncertain (and therefore could not be reliably predicted) would money (and all other liquid assets) always be nonneutral as they are used as a store of savings. In essence Keynes viewed the economic system as moving through calendar time from an irrevocable past to an uncertain, not statistically predictable, future. This required Keynes to reject the ergodic axiom.

Keynes never used the term "ergodic" since ergodic stochastic theory was first developed in 1935 by the Moscow School of Probability and it did not become well known in the West until after the second world war and Keynes was dead. Nevertheless Keynes's main criticism of Tinbergen's econometric "method" (Keynes, 1939a, p. 308) was that the economic data "is not homogeneous over time". Non-homogenous data over time means that economic time series are nonstationary, and nonstationary is a sufficient (but not a necessary condition) for a nonergodic stochastic process. Consequently, Keynes, with his emphasis on uncertainty had, in these comments on Tinbergen, specifically rejected what would 
Paul Davidson

later be called the ergodic axiom - an assumption that Samuelson has declared is a foundation necessary to make economics a hard science.

\section{Liquidity and contracts}

Nevertheless, the question may remain "Does applying Keynes's smaller axiomatic base make any difference in our understanding of the real world in which we live vis-a-vis applying Samuelson's classical axiomatic foundation version of Keynesianism?" The answer is definitely yes because only if we overthrow these three classical axioms that are an essential part of Samuelson's foundations of economic analysis can the concept of liquidity play an important role in our analysis - as it does in our lives.

The economy in which we live utilizes money contracts - not real contracts - to seal production and exchange agreements among self-interested individuals. The ubiquitous use of money contracts is an essential element of all real world entrepreneurial economies. Moreover recontracting without income penalty (an essential characteristic of the Walrasian system) whenever parties have entered into a contract at a price other than the implicit full employment general equilibrium price is never permitted under the civil law of contracts. Why, one might ask Samuelson, do economies continue to organize production and exchange on the basis of money contracts, if such use interferes with the rapid achievement of a socially optimal general Walrasian equilibrium?

The use of money contracts has always presented a dilemma to classical theorists. Logically consistent classical theorists must view the universal use of money contracts by modern economies as irrational, since such agreements fixing payments over time in nominal terms can impede the self-interest optimizing pursuit of real incomes by economic decision makers. Mainstream economists tend to explain the existence of money contracts by using non-economic reasons such as social customs, invisible handshakes, etc. - societal institutional constraints which limit price signaling and hence limits adjustments for the optimal use of resources to the long run.

For Keynes binding nominal contractual commitments are a sensible method for dealing with true uncertainty regarding future outcomes whenever economic activities span a long duration of calendar time. In organizing production and exchange on a money contractual basis, buyers need not be as unduly worried about what events happen in the uncertain future as long as they have, or can obtain, enough liquidity to meet these contractual commitments as they come due. Thus liquidity means survival in a money-using contractual entrepreneurial directed market economy Insolvency and bankruptcy, on the other hand, occurs when significant contractual monetary obligations can not be met and 
assets that were thought to be liquid can not be sold in an orderly market. Bankruptcy is the equivalent of a walk to the economic gallows.

Keynes's general theory emphasizes money and liquidity. All buyers need is the liquidity to meet money contractual obligations as they come due. This means that investment spending, which we normally associate with the demand for reproducible fixed and working capital goods, is not constrained by either actual current income or inherited endowments - as long as there is unemployed resources available. Investment can be a form of exogenous spending that is constrained, in a money-creating banking system, solely by the expected but uncertain future monetary (not real) cash inflow (Keynes, 1936, ch. 17) upon which banks are willing to make additional loans.

In a world where money is created primarily only if someone increases their indebtedness to banks in order to purchase newly produced goods, then financing of real investment spending will be undertaken as long as the buyer can convince lenders that the newly produced capital goods are expected to generate a future of net cash inflow exceeds the contractual cask outflow specified in the money debt contract.

Any component of aggregate demand is not necessarily constrained by actual income when buyers finance purchases by borrowing from a banking system that can create money. This Post Keynesian financing mechanism where increases in the nominal quantity of money are used to finance increased demand for producible goods results in increasing employment levels. Money, therefore, can not be neutral and can be endogenous.

To reject the neutrality axiom does not require assuming that agents suffer from a money illusion. It only means that "money is not neutral" (Keynes, 1935, p. 411) in the sense that money matters in both the short run and the long run, affecting the equilibrium level of employment and real output. If it weren't for Samuelson's (and Blanchard's) insistence on neutral money as a foundations for all macro economic theory, economists might recognize that in a money-using entrepreneurial economy that organizes production and exchange with the use of spot and forward money contracts, money is a real phenomenon. The money neutrality axiom must be rejected.

Arrow and Hahn (1971, p. 356-57) implicitly recognized this necessity of overthrowing the neutral money axiom when they wrote about the requirements of a serious monetary theory. Moreover Arrow and Hahn demonstrate (1971, p. 361) that, if production and exchange contracts are made in terms of money (so that money affects real decisions) in an economy moving along in calendar time with a past and a future, then all general equilibrium existence theorems are jeopardized. 
Paul Davidson

The existence of money contracts - a characteristic of the world in which we live - implies that there need never exist, in the long run or the short run, any rational expectations equilibrium or general equilibrium market clearing price vector. Samuelson's Walrasian foundation is not a reliable base for real world economies that use money and money contracts to organize economic activities.

\section{What about Hicks's is-LM model?}

Hicks (1939, p. 1-4) wrote that he "had the fortune to come upon a method of analysis. The method of General Equilibrium... was specially designed to exhibit the economic system as a whole... (With this method) we shall thus be able to see just why it is that Mr. Keynes reaches different results from earlier economists". Hicks (1937) used this general equilibrium method to develop his ISLM model where the real and monetary aspects of the economy are divided into independent subsets of equations. These independent subsets requires the neutral money axiom. Accordingly, this ISLM model is merely another classical theory version of Samuelson's neoclassical synthesis Keynesianism.

In 1971 I met John Hicks at a six day IEA conference on the microfoundations of macroeconomics. At the conference my participation (Davidson, 1977, p. 313-317) emphasized the importance of contracts and the existence of spot and forward markets, the need for liquidity, and the fact that a classical "general equilibrium model was not designed to, and could not answer the interesting macroeconomic questions of money, inflation and unemployment... (and) if we insist on balancing Keynes's macroeconomic analysis on an incompatible general equilibrium base we would not make any progress in macroeconomics; we would also regress to the disastrous pre-Keynesian solutions to the macro-political-economic problems" (Davidson, 1977, p. 392). By the end of the conference, Hicks informed me that the microfoundations of his approach to macroeconomics were closer to mine than to any one else at the conference (which included Nobel Prize winners Tinbergen and Stiglitz).

Over the next few years, Hicks and I met privately several times in the UK to continue our discussions regarding the microfoundation of Keynes's general theory. By the mid 1970's Hicks (1976, p. 140-141) was ready to admit that his IS-LM model was a "potted version" of Keynes. By 1979 Hicks (1979) was arguing that economics is embedded in calendar time and a relationship that held in the past could not be assumed to hold in the future (Hicks, 1979, p. 38) In a 1981 article in the Journal of Post Keynesian Economics entitled "ISLM: An Explanation", Hicks recanted his ISLM model when he wrote (Hicks, 1980-81, p. 139): "As time has gone on, I have myself become dissatisfied with it (the ISLM 
apparatus)". In this JPKE article, Hicks admitted that ISLM did not describe Keynes's general theory approach at all.

Finally, after reading my paper on the fallacy of rational expectations (Davidson, 1982-3), Hicks wrote to me in a letter dated February 12, $1983^{7}$ "I have just been reading your RE (rational expectations) paper... I do like it very much... You have now rationalized my suspicions, and shown me that I missed a chance of labeling my own point of view as nonergodic. One needs a name like that to ram a point home".

Thus the author of the IS-LM renounced his famous formulation of Keynes's framework and accepted the Post Keynesian view of what was the basic analysis of Keynes's General Theory analysis of the operation of a monetary economy.

\section{Conclusion}

Paul Samuelson saved the term "Keynesian" from being excoriated from post second world war textbooks by the McCarthy anti-communist movement at the time. But the cost of such a saving was to sever the meaning of Keynes's theory in mainstream economic theory from its General Theory analytical roots. Keynes's revolution was to demonstrate that in a money using, market-oriented economy, supply-side market imperfections including the fixity of money wages and/or prices or a liquidity trap are not necessary conditions for the existence of involuntary unemployment equilibrium, while flexible wages and prices and pure competition are not sufficient conditions to assure full employment equilibrium, even in the long run.

Samuelson's view of Keynesianism resulted in aborting Keynes's revolutionary analysis from altering the foundation of mainstream macroeconomics. In winning the battle against the forces trying to prevent the teaching of suspected communist inspired "Keynesian" economics in our universities, Samuelson ultimately lost the war that Keynes had launched to eliminated the classical theoretical analysis as the basis for real world economic problems of employment, interest and money. In 1986 Lorie Tarshis recognized this when he noted "I never felt that Keynes was being followed with full adherence or full understanding of what he had written. I still feel that way" (C-L, p. 72).

(7) This letter is available in the collection of my correspondence that is on deposit at the Duke University Library Archives of economists's correspondence and writings. 
Paul Davidson

Mainstream economics - whether espoused by Old Neoclassical Keynesians, New Keynesians, Old Classical or New Classical theorists, etc. ${ }^{8}$ relies on the three classical axioms that Keynes discarded in his general theory attempt to make economics relevant to the real world problems of unemployment and international trade and international payments. As a result these problems still plague much of the real world in the globalized economy of the 21 century.

Until mainstream journal of economics open their pages to the revolutionary (fewer axiomatic base) of Keynes's general theory of a monetary economy, mainstream economists will not be able to provide policy prescriptions for resolving the major economic problems (e.g., outsourcing, persistent US current account deficits, increasing inequality of income and wealth within nations as well as between nations, the global financial problem created by the securitization of US sub prime mortgages) of the global economy of the 21st century. Until then the best we can hope for is that the global economy muddles through without another great calamity such as the Great Depression of the 1930s. But when, not if, the next Great Depression hits the global economy, then perhaps economists will rediscover Keynes's general theory analytical system that contributed to the golden age of the post second world war II. For Keynes, however, that will be a Pyrrhic victory.

\section{References}

ARROW, K. W.; HAHN, F. H. General competitive analysis. Holden-Day, San Francisco, 1971.

BLANCHARD, O. J. Why does money affect output? A survey. In: FRIEDMAN, B. M.; HAHN, F. H. (Ed.). Handbook of monetary economics, II. New York: Elsevier, 1990.

BUCKLEY, W. F. God and Man at Yale. Chicago: Henry Rigney, 1951.

COLANDER, D. C.; LANDRETH, H. The coming of Keynesianism to America. Elgar, Cheltenham, 1996.

(8) Some economists, e.g., behavioral theorists, have tried to erect ad hoc models suggesting that agents do not always act with the economic rationality of classical theory's decision makers although there is nothing in their analysis that denies the possibility that rational decision making is possible. Unfortunately, such theories have no unifying underlying general theory to explain why such "irrational" behavior exists. Behavioral theorists can not explain why those who undertake non-rational behavior have not been made extinct by a Darwinian struggle with those real world decision makers who take the time to act rationally. Had behavioral theorists adopted Keynes's general theory as their basic framework, irrational behavior can be explained as sensible if the economy is a non-ergodic system. Or as Hicks (1977, p. vii) succinctly put it, "One must assume that the people in one's models do not know what is going to happen, and know that they do not know just what is going to happen." In conditions of true uncertainty, people often realize they just don't have a clue as to what rational behavior should be. 
DANZIGER, S.; VAN DER GAAG, J.; SMOLENSKY, E.; TAUSSIG, M. K. The life cycle hypothesis and the consumption behavior of the elderly. Journal of Post Keynesian Economics, v. 5, 1982-83.

DAVIDSON, P. Money and the real world. London: Macmillan, 1972.

Rational expectations: a fallacious foundation for studying crucial decisionmaking processes. Journal of Post Keynesian Economics, v. 5, 1982-83.

Post Keynesian employment and analysis and the macroeconomics of OECD employment. The Economic Journal, v. 108, 1998.

Financial markets money and the real world. Elgar, Cheltenham, 2002.

John Maynard Keynes. New York: Palgrave/Macmillan, 2007.

GALBRAITH, J. K. Keynes, Einstein, and the scientific revolution. In: ARESTIS, P. (Ed.). Keynes, money and the open economy. Cheltenham: Elgar, 1996.

HAHN, F. A. Keynesian economics and general equilibrium theory. In: HARCOURT, G. C. (Ed.). The microfoundations of macroeconomics. London: Macmillan, 1977.

HICKS, J. R. Mr. Keynes and the classics: a suggested interpretation. Econometrica, v. 5, p. 147-149, Apr. 1937.

Value and capital. Oxford: Oxford University Press, 1939.

Some questions of time. In: TANG, M. et al. (Ed.). Economics in evolution, welfare and time in economics. Lexington: Heath Books, 1976.

Causality in economics. New York: Basic Books, 1979.

ISLM: an explanation. Journal of Post Keynesian Economics, v. 3, 1980-1.

KEYNES, J. M. (1935). A monetary theory of production. In: MOGGRIDGE, D. (Ed.). The Collected Writings of John Maynard Keynes, XIII. London: Macmillan, 1973a. All references are to reprint.

The General Theory of Employment, Interest, and Money. New York: Harcourt, Brace, 1936.

(1937). The General Theory. Quarterly Journal of Economics. Reprinted in: MOGGRIDGE, D. (Ed). The Collected Writings of John Maynard Keynes, XIV. London: Macmillan, 1973. All references are to reprint.

(1938). Letter to R. F. Harrod'. Reprinted in: MOGGRIDGE, D. (Ed.). The Collected Writings of John Maynard Keynes, XIV. London: Macmillan, 1973. All references are to reprint.

(1939a). Professor Tinbergen's Method. Economic Journal, 49. Reprinted in: MOGGRIDGE, D. (Ed.). The Collected Writings of John Maynard Keynes, XIV. London: Macmillan, 1973. All references are to reprint.

(1939b). Relative movements of real wages and output. The Economic Journal, 49. Reprinted in: MOGGRIDGE, D. (Ed.). The Collected Writings of John Maynard Keynes, XIV. London: Macmillan, 1973. All references are to reprint. 
Paul Davidson

SAMUELSON, P. A. Foundations of economic analysis. Cambridge: Harvard University Press, 1947.

Economics: an introductory analysis. New York: McGraw-Hill, 1948.

SKIDELSKY, R. John Maynard Keynes, The economist as Saviour 1920-1937. London: Macmillan, 1992.

WEINTRAUB, E. R. How economics became a mathematical science. Durham: Duke University Press, 2002. 